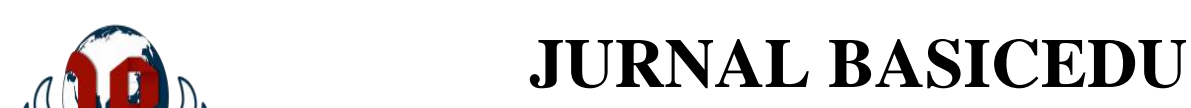

Volume 5 Nomor 4 Tahun 2021 Halaman 2348 - 2357

Research \& Learning in Elementary Education

https://jbasic.org/index.php/basicedu

\title{
Pengembangan Game Math-Venture terhadap Pemecahan Masalah Matematika di Sekolah Dasar
}

\author{
Hesti Agustianingrum $^{1 凶}$, Yohana Setiawan $^{2}$ \\ Universitas Kristen Satya Wacana, Indonesia ${ }^{1,2}$ \\ E-mail: hestiagustia0@ gmail.com ${ }^{1}$
}

\begin{abstract}
Abstrak
Kurikulum 2013 (K13) merupakan kurikulum dengan basis pendidikan karakter serta menekankan pada kreativitas dan inovasi siswa. Pada era ini memerlukan inovasi media pembelajaran. Permasalahan yang terjadi di Sekolah Dasar adalah kurang antusiasnya peserta didik terhadap pembelajaran yang monoton. Tujuan dari penelitian ini adalah mengembangkan media pembelajaran "Math-Venture" untuk mengetahui keterampilan siswa dalam pemecahan masalah matematika di kelas 4 SD . Penelitian Research and Development (R\&D) yang digunakan adalah milik Borg and Gall. Penelitian ini menggunakan model ADDIE, instrumen penelitian yang digunakan yaitu menggunakan kuesioner oleh validator materi dan media. Hasil dari validasi produk game Math-Venture mendapat hasil validasi materi $81 \%$ termasuk dalam kategori sangat tinggi. Hasil validasi media memperoleh skor $91 \%$ termasuk dalam kategori sangat tinggi, dengan rata rata hasil validasi $86 \%$. Sehingga dalam pembuatan produk media pembelajaran dapat dinyatakan media pembelajaran Math-venture layak untuk digunakan sebagai media pembelajaran.
\end{abstract}

Kata Kunci: Math-Venture, media, pemecahan masalah, matematika SD.

\begin{abstract}
Kurikulum 2013 (K13) is one of the curriculums with the character education base and emphasizes students' creativity and innovativeness. In this era, learning media innovation is needed because of the problem that occurs in primary school such as the lack of students' enthusiasm towards monotonous learning. The goal of this research was to develop learning media called "math-venture" to know student skills solve math problems in 4th grade of elementary school. This research was Research and Development $(R \& D)$ by Borg and Gall and the method of this research was ADDIE model. The instrument was a questionnaire toward content and media validators. The result of game Math-Venture based on content validator was $81 \%$ which was a very high category. The result of media validations gets $91 \%$ it was included in very high category with the average of validation result $86 \%$. Therefore, in creating learning media product could be stated that learning media MathVenture was suitable to be used as a learning media.
\end{abstract}

Kata Kunci: Math-Venture, media, problem solve, mathematic primari school

Copyright (c) 2021 Hesti Agustianingrum, Yohana Setiawan

$\triangle$ Corresponding author :

Email: hestiagustia0@gmail.com

DOI : https://doi.org/10.31004/basicedu.v5i4.1221

ISSN 2580-3735 (Media Cetak)

ISSN 2580-1147 (Media Online) 


\section{PENDAHULUAN}

Menurut (Depdiknas, 2010) pendidikan karakter adalah segala sesuatu yang dilakukan guru, yang mampu mempengaruhi karakter peserta didik. Kurikulum 2013 merupakan tindak lanjut dari kurikulum berbasis kompetensi (Competency Based Curriculum) dijadikan acuan dan pedoman bagi pelaksanaan pendidikan untuk mengembangkan berbagai ranah pendidikan (pengetahuan, keterampilan, dan sikap) dalam seluruh jenjang dan jalur pendidikan, khususnya pada jalur pendidikan sekolah (E, Mulyasa, 2014). Siswa akan lebih kreatif, inovatif, dan lebih produktif, sehingga nantinya mereka bisa sukses dalam menghadapi berbagai persoalan dan tantangan di zamannya, memasuki masa depan yang lebih baik.

Hasil dari analisis beberapa jurnal tentang permasalahan materi KPK permasalahan yang terjadi dalam pembelajaran KPK dimana yang terjadi adalah peserta didik sering kali sulit dalam pemahaman materi KPK masih banyak siswa yang belum memahami sepenuhnya tentang bilangan prima dan bagaimana menentukan faktor-faktor prima suatu bilangan, sehingga dalam pembelajaran KPK belum mendapatkan hasil yang maksimal, Sehingga perlu diberikan wawasan yang lebih mendasar tentang faktor komposit suatu bilangan dan faktor persekutuan dua bilangan atau lebih terlebih dahulu. Menurut salah satu peneliti Nur Qurrota A'yun menyatakan bahwa mereka tidak senang belajar Matematika karena menurut mereka Matematika sulit untuk dipahami, dan penuh dengan rumus-rumus Dalam penelitian ini, peneliti membuat media pembelajaran yang menginovasikan pembelajaran menjadi sebuah permaian seperti kecenderungan anak pada zaman sekarang. Pada era ini juga, guru dituntut untuk membuat inovasi suasana, pembelajaran baru supaya tidak monoton dan siswa tidak merasa bosan saat pembelajaran berlangsung. Media pembelajaran adalah faktor penting dalam proses pembelajaran, maka dari itu penulis mengembangkan media game yang menarik yang dapat menarik antusias peserta didik dalam mengikuti pembelajaran yang berlangsung. Dari permasalahan ini maka peneliti merumuskan seberapa kelayakan produk dan mengetaui tingkat getahkelayakan "Game Math-Venture" Peneliti sendiri akan membuat media pembelajaran yang berupa game. Game sendiri adalah kata dalam bahasa inggris yang artinya permainan atau pertandingan. Game dibuat sebagus mungkin untuk menarik setiap peserta didik. Jadi dapat disimpulkan bahwa media pembelajaran game merupakan suatu permainan yang dalam pengoperasianya menggunakan media dan di dalamnya terdapat peraturan dan permasalahanya yang harus diselesaikan atau misi yang akan dicapai atau tujuan yang ingin dituju.

Tujuan dan pentingnya dibuatnya media pembelajaran Math-Venture, adalah sebagai media pembelajaran yang dapat membantu peserta didik dalam memudahkan mengikuti proses belajar mengajar dan dapat menarik antusiasme peserta didik sehingga dalam pembelajaran anak lebih mendapatkan pengalaman pribadi dalam belajar, dan dapat memaksimalkan hasil dari proses belajar mengajar. Terlebih kondisi pandemi covid-19 saat ini membuat peneliti yakin untuk membuat pengambangan game Math-Venture ini. Menurut Borg and Gall (Siti Rabiah, 2015)) Penelitian R\&D adalah suatu proses yang yang digunakan untuk mengembangkan dan mengesahkan produk bidang pendidikan . Ada sepuluh proses yang dibutuhkan untuk kegiatan pengembangan dan memvalidasi suatu produk, tetapi hanya dapat dilaksanakan hingga validasi ahli dan tidak dapat uji ke lapangan untuk menguji coba produk.

Produk Math-Venture yang dikembangkan oleh peneliti lakukan memiliki keunikan adalah yang pertama sudah menyesuaikan dengan kepribadian siswa dimana dalam usia ini peserta didik masih dalam tahap suka bermain maka peneliti membuat media game. Yang kedua, keunikan media ini dibandingkan yang lain terdapat pembahasan setelah mengerjakan soal jadi jika peserta didik salah dalam mengerjakan soal maka peserta didik dapat melihat pembahasan yang ada sehingga dapat dipelajari kembali. Yang ketiga, game ini dapat diakses dimana saja dan kapan saja sehingga memudahkan peserta didik dalam mengakses game ini. Media pembelajaran sendiri yang dimaksut adalah alat yang dapat digunakan dalam membantu proses belajar mengajar dan memiliki fungsi dalam memperjelas materi atau makna pesan yang disampaikan dan sebagai alat bantu dalam pembelajaran yang melibatkan interaksi antara guru dan siswa. (Mawardi, 2014) Pembelajaran adalah 
kegiatan siswa melalui usaha yang direncanakan dengan memanipulasi sumber-sumber ataupun bahan ajar belajar agar tercipta proses pembelajaran. Dengan demikian maka dapat ditarik kesimpulan bahwa hakikat media pembelajaran yaitu, segala sesuatu yang digunakan sebagai sarana guna menyalurkan pesan maupun informasi bahan ajar sehingga tercipta proses pembelajaran yang melibatkan interaksi antara siswa dan guru untuk mencapai tujuan pembelajaran.

Matematika berperan penting pada pengembangan Teknologi Informasi dan Komunikasi (TIK). Matematika merupakan sebuah ilmu yang mempelajari tentang bilangan, bangun, hubungan antar konsep, dan logika dengan penggunaan simbol atau bahasa lambang dalam menyelesaikan permasalahan kehidupan seharihari (H, Suhendri, 2011) Peserta didik dapat lebih aktif dalam belajar mengambil tanggung jawab yang lebih besar seperti mencari informasi, mengolah informasi, membuat kesimpulan, mempraktikkan, dan untuk kemudian diterapkan. TIK merupakan suatu hal yang tidak asing lagi, bahkan bagi peserta didik usia Sekolah Dasar. Permasalahan dalam pembelajaran matematika SD umumnya peserta didik dapat menghafal konsep yang dibelajarkan oleh guru namun peserta didik kurang memaksimalkan penggunaan konsep tersebut jika menemui kendala atau permasalahan dalam kehidupan sehari-hari sehingga peserta didik kurang memahami masalah yang sedang dihadapi dan kurang mampu merumuskannya.

Pemecahan masalah yaitu sebuah bagian dari kurikulum Matematika yang dinilai menjadi hal yang penting pada proses pembelajaran Matematika (Mariam S, 2019) Dengan adanya pemecahan masalah, maka kemampuan dalam memecahkan permasalahan secara matematis misalnya pada penemuan pola, mengeneralisasikan, melakukan komunikasi matematis serta hal lainnya bisa dikembangkan dengan baik pula. Hal ini sejajar dengan makna belajar bahwa adanya pemecahan masalah merupakan bagian yang termasuk penting. Menurut George Polya (Ely Wardani, 2020)) ada empat tahap pemecahan masalah, yaitu memahami masalah, merencanakan penyelesaian masalah, melakukan perencanaan masalah, dan melihat kembali hasil yang diperoleh. Empat tahapan Polya adalah sebagai berikut : a) Memahami Masalah (Understand the Problem), b) Membuat rencana (Devise a Plan), c) Melaksanakan rencana (Carry Out the Plan), dan d) Melihat kembali (Looking Back).

Berdasarkan pernyataan-penyataan diatas maka dikembangkan suatu produk media pembelajaran "MathVenture" terhadap pemecahan masalah khususnya pada mata pelajaran matematika. Dalam pengembangan media ini hanya difokuskan pada materi kelas IV semester 1 materi Kelipatan Persekutuan TerKecil (KPK). Pengembangan media pembelajaran ini ada beberapa kelebihan, antara lain game ini dibuat dalam bentuk sebuah permainan yang dapat di akses melalui android ataupun laptop menjadi lebih praktis dalam memainkannya, sehingga anak dapat memainkan game pembelajaran kapan saja dan dimana saja. Bentuk game Math-Venture ini berupa petualangan yang nantinya siswa akan mencari kunci yang akan ada soal soal yang harus dijawab agar dapat menyelesaikan permainan dengan baik. Untuk itu tujuan penelitian ini adalah menguji validitas media pembelajaran Math-Venture dalam pemecahan masalah matematika kelas IV sekolah dasar

\section{METODE}

Penelitian ini menggunakan jenis Penelitian dan Pengembangan atau Research and Developmen (R\&D). Penelitian R\&D menurut Borg and Gall (Siti Rabiah, 2015)) adalah suatu proses yang yang digunakan untuk mengembangkan dan mengesahkan produk bidang pendidikan. Ada sepuluh proses yang dibutuhkan untuk kegiatan pengembangan dan memvalidasi suatu produk pendidikan prosedur penelitian pengembangan menurut metode Borg and Gall yaitu meliputi: Penelitian dan pengumpulan informasi (research and information collecting), perencanaan (planning), pengembangan produk awal (develop preliminary form of product), uji coba lapangan (preliminary field testing), penyempurnaan produk awal (main product revision), uji coba lapangan (main field testing), menyempurnakan produk hasil uji lapangan (operational product revision), uji pelaksanaan lapangan (operasional field testing), penyempurnaan produk akhir (final product revision), dan diseminasi dan implementasi (disemination and implementation). 
2351 Pengembangan Game Math-Venture terhadap Pemecahan Masalah Matematika Di Sekolah DasarHesti Agustianingrum, Yohana Setiawan

DOI: https://doi.org/10.31004/basicedu.v5i4.1221

Penelitian ini dilaksanakan dengan model pengembangan ADDIE (Sugiyono, 2015: 200) menjelaskan bahwa model ADDIE (Analysis, Design, Development, Implementation, dan Evaluation). Dalam pelaksanaan penelitian ini bertujuan untuk mengembangkan media game Math-Venture terhadap pemecahan masalah, mengetahui kevalidan Math-Venture dan mengetahui tingat keefektifan media pembelajaran game MathVenture.

Teknik pengumpulan data kuantitatif yang digunakan dalam penelitian dan pengembangan Math-Venture menggunakan teknik non tes dengan kuesioner. Penilaian kelayakan media yang dilakukan oleh validator diolah menggunakan rating scale dengan empat skala.

Teknik analisis data uji validasi ahli materi menggunakan teknik deskriptif kualitatif dan presentase untuk menunjukan tingkat validitas materi pembelajaran Kelipatan Persekutuan TerKecil siswa kelas IV Sekolah Dasar. Menurut (Mawardi, 2014) cara yang digunakan dengan melihat hasil dari pengukuran menggunakan rumus:

Keterangan

$$
\mathrm{AP}=\frac{\text { Skor Aktual }}{\text { Skor Ideal }} \times 100 \%
$$

AP

: Angka presentase

Skor Aktual : Skor yang diberikan oleh validator ahli

Skor Ideal : Skor masimal hasil kali antara jumlah item dengan skor masing-masing item

Angka presentasse tersebut selanjutnya dikelompokan menjadi lima kategori berikut ini:

Tabel 1

Indeks Validasi Ahli

\begin{tabular}{ll}
\hline \multicolumn{1}{c}{ Interval } & \multicolumn{1}{c}{ Kategori } \\
\hline $81-100 \%$ & Sangat Tinggi \\
\hline $61-80 \%$ & Tinggi \\
\hline $41-600 \%$ & Cukup \\
\hline $0-20 \%$ & Rendah \\
\hline
\end{tabular}

Menurut (Mawardi 2014:113) hasil uji validasi media pembelajaran "Game Math-Venture" dapat dikatakan layak diujicobakan apabila presentase minimal mencapai kategori tinggi yaitu $\geq 60 \%$. Media pembelajaran Math-Venture dikatakan efektif untuk pemecahan masalah matematika apabila kriteria hasil ketuntasan berapa pada interval $81 \%-100 \%$

\section{HASIL DAN PEMBAHASAN}

R\&D menurut Borg and Gall (Siti Rabiah, 2015)) yaitu proses yang dibutuhkan untuk kegiatan pengembangan dan memvalidasi suatu produk pendidikan. Ada tiga prosedur penelitian pengembangan yang diterapkan oleh peneliti menurut metode Borg and Gall yaitu: yang pertama penelitian dan pengumpulan informasi (research and information collecting). Tujuan dari metode ini yakni untuk mengumpulkan informasi tentang produk yang akan dikembangkan serta mengidentifikasi masalah yang mungkin saja dapat dijumpai dalam pengembangan produk. Kedua perencanaan (planning) di tahap ini terdapat langkah yang harus dilakukan yaitu merumuskan tujuan penelitian, memperkirakan tenaga, waktu dan dana, merumuskan kualifikasi peneliti dan juga bentuk partisipasinya. Ketiga pengembangan produk awal (develop preliminary form of product) tahap ini merupakan tahap permulaan dari produk yang akan dihasilkan. Yang meliputi: pedoman petunjuk, evaluasi terhadap kelayakan alat, mempersiapkan instrumen-instrumen untuk validator produk. 
2352 Pengembangan Game Math-Venture terhadap Pemecahan Masalah Matematika Di Sekolah DasarHesti Agustianingrum, Yohana Setiawan

DOI: https://doi.org/10.31004/basicedu.v5i4.1221

Model pengembangan dalam penelitian ini adalah model ADDIE (Sugiyono, 2015:200)) yang terdiri dari lima langkah pengembangan meliputi: pertama, tahap analisis tahap pertama pada model ADDIE adalah melakukan analisis terhadap peserta didik yang melakukan pembelajaran. Kedua, tahap perancangan yaitu tahap yang dilakukan setelah selesai melakukan prapenelitian yang bertujuan untuk merancang media pembelajaran berupa "Game Math-Venture" dengan materi KPK. Ketiga, tahap pengembangan pada tahap ini dilakukan setelah membuat media "Game Math-Venture" dengan materi Kelipatan Persekutuan TerKecil. Keempat, tahap implementasi pada tahap ini diimplementasikan "Game Math-Venture" dengan materi Kelipatan Persekutuan TerKecil. Kelima, tahap evaluasi Tahap ini digunakan untuk mengukur kelayakan dari media pembelajaran "Game Math-Venture" yang sudah dikembangkan untuk menciptakan pembelajaran yang efektif.

Penelitian yang telah dilakukan, dalam tahap studi pendahuluan ini peneliti melakukan penelitian dengan cara melakukan wawancara terhadap guru kelas SD St.Marsudirini 77 untuk mendapatkan informasi mengenai kebutuhan produk yang akan dibuat terkhusus dalam pembelajaran matematika kelas IV Sekolah Dasar materi Kelipatan Persekutuan TerKecil (KPK). Hasil wawancara diperoleh informasi, dalam pembelajaran matematika terkhusus materi KPK siswa merasa kurang antusias akan media yang digunakan guru sebagai media pembelajaran, siswa juga kurang fokus dalam mengikuti pembelajaran. Siswa saat ini lebih tertarik dengan media yang berbau dengan Smartphone. Dari permasalahan ini maka guru memerlukan sebuah inovasi media pembelajaran yang dapat membut siswa menjadi lebih antusias dan memahami materi dengan baik sehingga dapat memecahkan masalah matematika terkhusus materi KPK kelas IV Sekolah Dasar. Dalam permasalahan ini, guru memberikan saran kepada peneliti supaya dapat membuat media yang dapat diakses menggunakan Smartphone maupun laptop, kapan saja dan dimana saja, sehingga ketika pembelajaran belum dipahami dapat diulang kembali dengan mudah.

Peneliti dalam hal ini akan berkontribusi dalam pembuatan media pembelajaran yang dapat diakses menggunakan Smartphone yang di harapkan dapat siswa dapat memecahkan masalah matematika. Hal lain yang akan didapatkan siswa adalah pembelajaran yang baru tidak membosankan sehingga pembuatan produk ini akan menarik perhatian siswa dan siswa dapat dengan baik untuk mengikuti pembelajaran di kelas. Dari permasalahan yang ada, maka peneliti akan mengembangkan produk penelitian berupa media game MathVenture terhadap pemecahan masalah di kelas IV Sekolah Dasar terkhusus pada Kelipatan Persekutuan TerKecil (KPK).

Ketika game dimulai akan masuk di halaman menu utama seperti gambar 1. Di halaman tersebut terdapat beberapa ikon yaitu petunjuk, kompetensi, materi, tujuan dan main. Dan semua dapat diakses sesuai perintah pemain. Ketika petunjuk di klik akan muncul seperti gambar 2, yaitu cara menggunakan game.

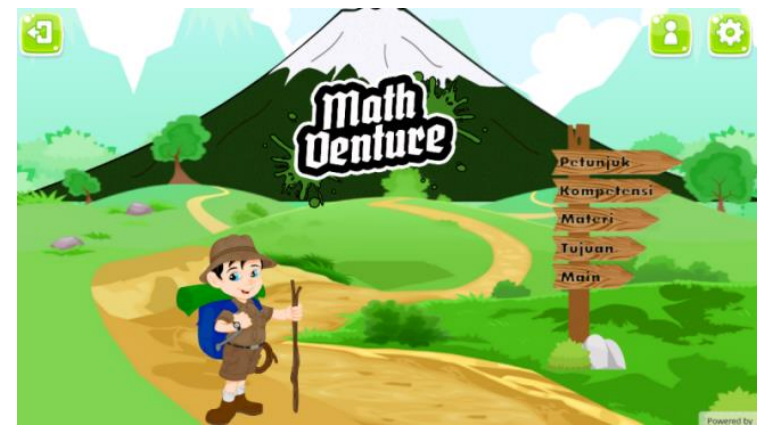

Gambar 1. Halaman Menu Utama

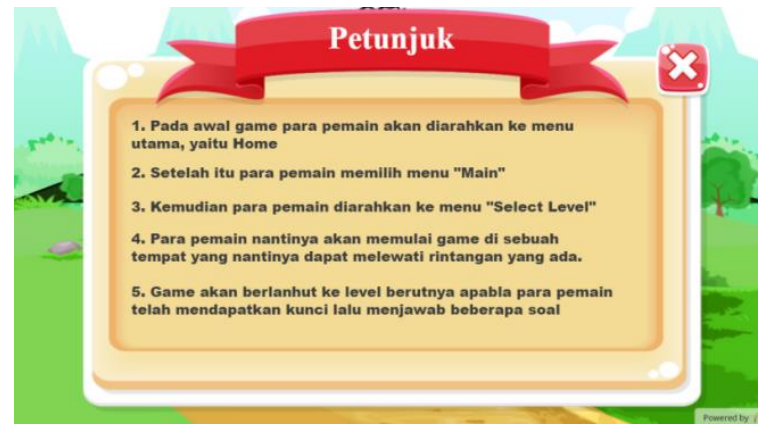

Gambar 2. Halaman Petunjuk

Kemudian pada ikon Materi maka akan muncul seperti gambar 3, gambar 4 dan gambar 5 yaitu materi tentang kelipatan, kelipatan persekutuan dan kelipatan persekutuan terkecil. 
2353 Pengembangan Game Math-Venture terhadap Pemecahan Masalah Matematika Di Sekolah DasarHesti Agustianingrum, Yohana Setiawan

DOI: https://doi.org/10.31004/basicedu.v5i4.1221

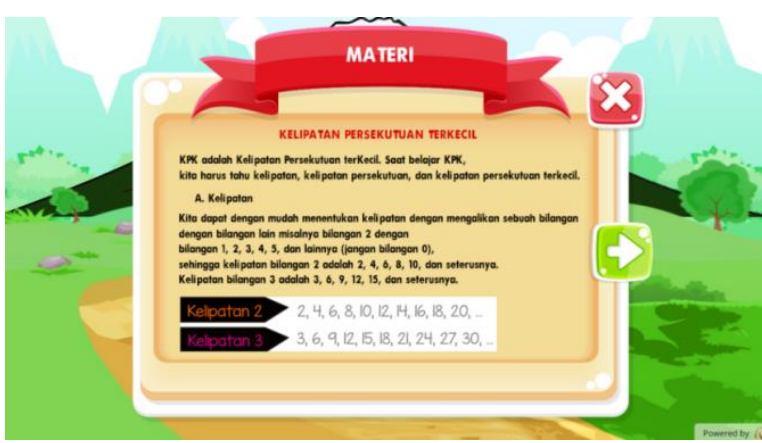

Gambar 3. Materi Kelipatan

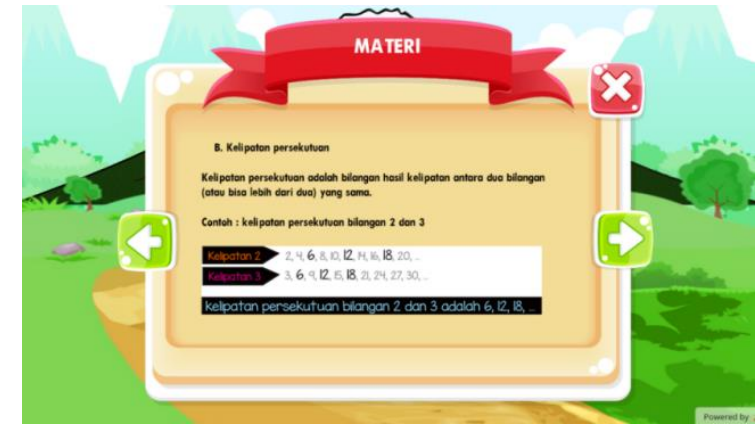

Gambar 4. Materi Kelipatan Persekutuan

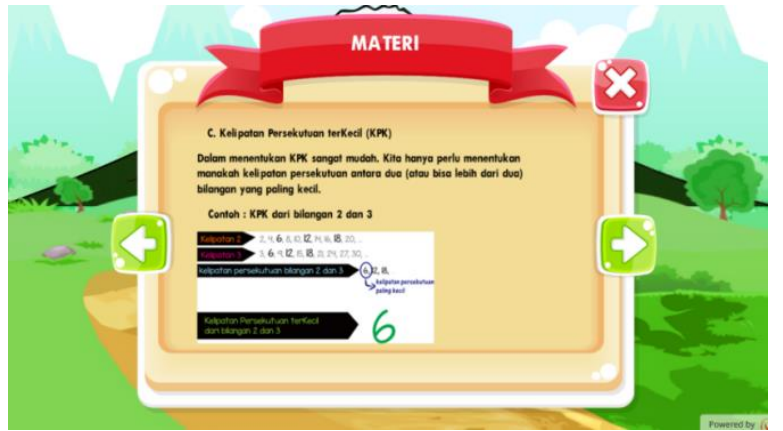

Gambar 5. Materi Kelipatan Persekutuan Terkecil

Pada gambar 6 yaitu Kompetensi dasar yang diangkat untuk pembuatan media game Math -Venture. Dan kemudian lanjut di ikon Tujuan seperti gambar 7 yaitu tujuan dari game tersebut.

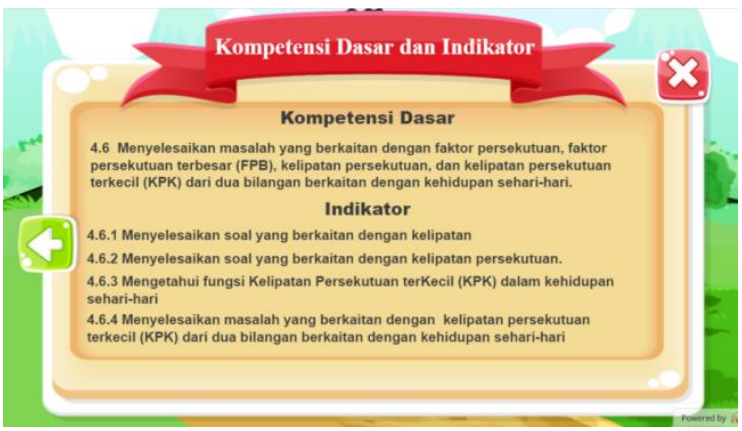

Gambar 6. Kompetensi

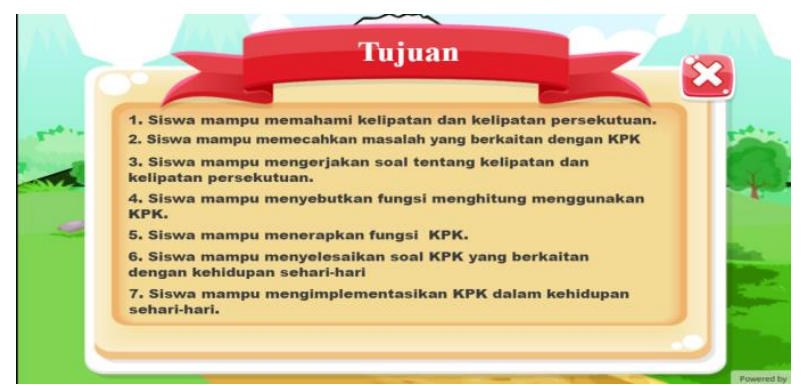

Gambar 7. Tujuan

Pada ikon Main muncul seperti gambar 8 yaitu absensi, maka wajib mengisi nama dan nomor absen, kemudian lanjut pada nomor 9 untuk memulai permainan yaitu dengan mengerjakan soal dalam game tersebut. Setelah semua soal dikerjakan akan muncul pembahasan soal seperti di gambar 10 dan juga akan muncul skor akhir pada gambar 11. Pada halaman terakhir yaitu profil pengembangan game Math Venture seperti gambar 12.

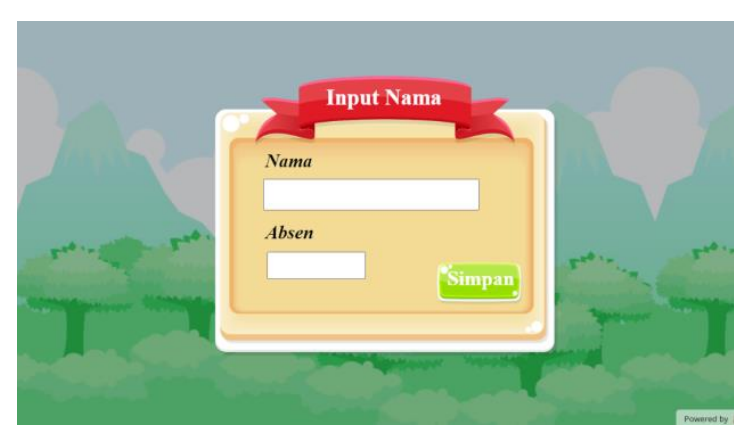

Gambar 8. Absensi

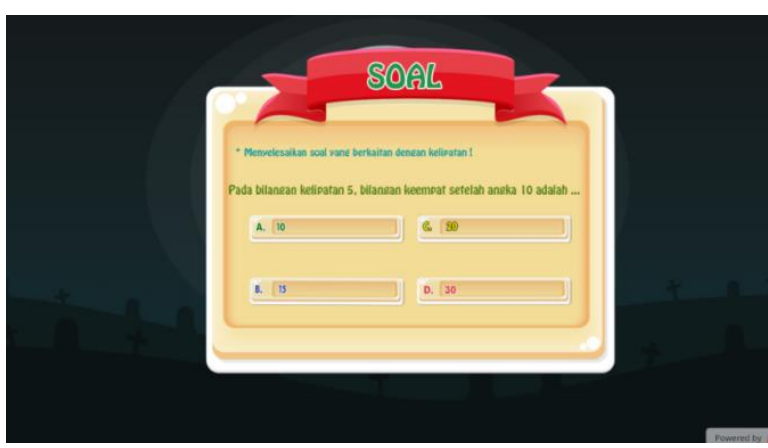

Gambar 9. Soal 


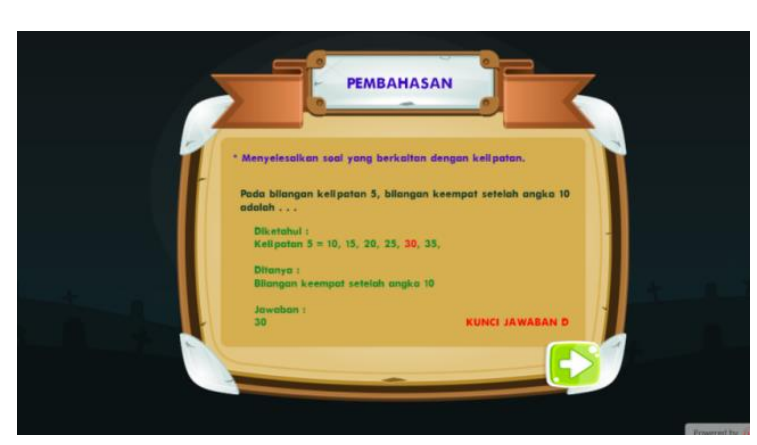

Gambar 10. Pembahasan Soal

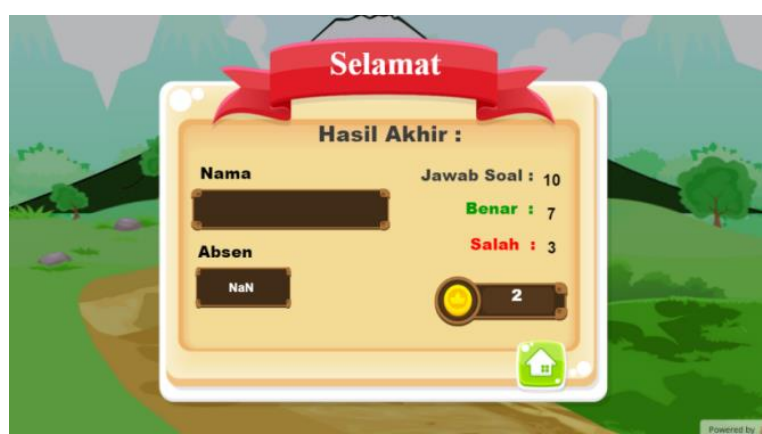

Gambar 11. Skor Akhir

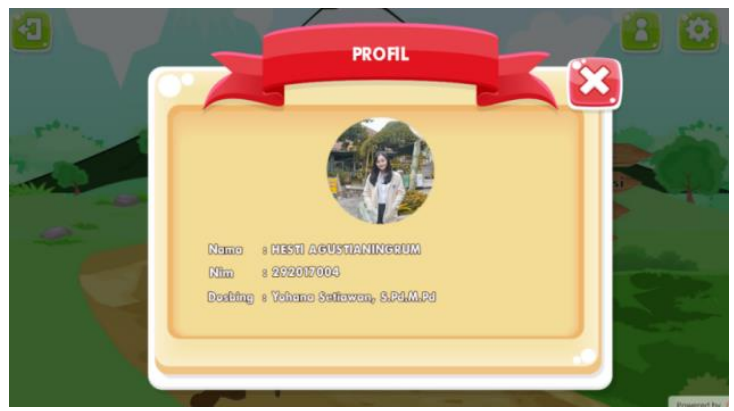

Gambar 12. Profil Peneliti

Setelah tahap draf produk akan dilanjutkan ke menguji produk kepada ahli. Terdapat 2 proses uji validasi yang dilakukan yaitu uji validitas materi dan uji validitas media oleh Dosen Universitas Kristen Satya Wacana. Uji validasi media yaitu untuk mengetahui kelayakan dalam segi aspek media yang digunakan dalam pembuatan media game Math-Venture terhadap pemecahan masalah kelas 4 SD. Menurut (Efendi, E \& Zhuang, 2005) yaitu: tampilan, interaksi, kontrol, dan bentuk. Hasil validasi media akan dijabarkan pada table

Tabel 2

Uji Validasi Media

\begin{tabular}{ccc}
\hline Aspek & Skor/Persentase & Kriteria \\
\hline Tampilan & $75 \%$ & Tinggi \\
\hline Interaksi & $100 \%$ & Sangat Tinggi \\
\hline Kontrol & $94 \%$ & Sangat Tinggi \\
\hline Bentuk & $81 \%$ & Sangat Tinggi \\
\hline Rata-rata hasil validasi aspek media & $\mathbf{8 9 \%}$ & Sangat Tinggi \\
\hline
\end{tabular}

Selanjutnya adalah hasil uji tingkat validitas materi pembelajaran dari produk game Math-Venture Terhadap Pemecahan Masalah Di Kelas IV Sekolah Dasar. Hasil dari validasi ahli materi memperoleh skor 81\% dan tergolong dalam interval 81\%-100\% (Mawardi, 2014) termasuk dalam kategori sangat tinggi. Hasil validasi materi menurut Kompetensi Dasar akan dijabarkan pada table 2.

Tabel 3

Uji Validasi Materi

\begin{tabular}{ccc}
\hline Aspek & Skor/persentase & Kriteria \\
\hline Kompetensi dasar pengetahuan & $87 \%$ & Sangat Tinggi \\
\hline Kompetensi dasar keterampilan & $81 \%$ & Sangat Tinggi \\
\hline Rata-rata hasil validasi aspek materi & $\mathbf{8 4 \%}$ & Sangat Tinggi \\
\hline
\end{tabular}

Produk media pengembangan game Math-Venture terhadap pemecahan masalah matematika kelas 4 SD layak digunakan sesuai saran yang diberikan oleh ahli materi dan media pembelajaran. Berikut tabel 3 hasil dari validasi ahli media dan materi menurut pemecahan masalah Polya. Hasil validasi akan dijabarkan pada tabel 3. 


\section{Tabel 4}

Uji Ahli Media dan Materi Menurut Polya

\begin{tabular}{ccccc}
\hline \multirow{2}{*}{ Aspek } & \multicolumn{2}{c}{ Ahli Media } & \multicolumn{2}{c}{ Ahli Materi } \\
\cline { 2 - 5 } & Presentase & Kriteria & Presentase & Kriteria \\
\hline $\begin{array}{c}\text { Memahami } \\
\text { masalah }\end{array}$ & $94 \%$ & Sangat Tinggi & $87 \%$ & Sangat Tinggi \\
\hline $\begin{array}{c}\text { Perencanaan } \\
\text { masalah }\end{array}$ & $92 \%$ & Sangat Tinggi & $83 \%$ & Sangat Tinggi \\
\hline $\begin{array}{c}\text { Melaksanakan } \\
\text { perencanaan }\end{array}$ & $87 \%$ & Sangat Tinggi & $75 \%$ & Tinggi \\
\hline $\begin{array}{c}\text { Pemeriksaan } \\
\text { kembali proses } \\
\text { dan hasil }\end{array}$ & $92 \%$ & Sangat Tinggi & $75 \%$ & Tinggi \\
\hline Skor total & $\mathbf{9 1 \%}$ & Sangat Tinggi & $\mathbf{8 1 \%}$ & $\begin{array}{c}\text { Sangat } \\
\text { Tinggi }\end{array}$ \\
\hline
\end{tabular}

Hasil dari validasi produk game Math-Venture mendapat hasil validasi media 91\% termasuk dalam kategori sangat tinggi. Hasil validasi materi memperoleh skor $81 \%$ termasuk dalam kategori sangat tinggi, dengan rata rata hasil validasi $86 \%$ maka media game pembelajaran ini masuk dalam interval $81 \%-100 \%$ sehingga dapat dinyatakan media pembelajaran Math-Venture layak untuk digunakan sebagai media pembelajaran.

Pada tahap pengujian terbatas dan uji lebih luas di sekolah dasar tidak dapat dilakukan karena keadaan dan kondisi pandemi covid-19 yang tidak memungkinkan untuk melakukan uji coba terbatas maupun uji coba luas karena aturan pemerintah yaitu belajar di rumah. Dari evaluasi ini peneliti mendapat banyak saran yang dapat digunakan untuk mengukur kelayakan dari media Math-Venture yang sudah dikembangkan untuk membantu siswa memecahkan masalah matematika.

Penelitian pengembangan media game Math-Venture terhadap pemecahan masalah di kelas IV Sekolah Dasar ini memiliki beberapa keterbatasan salah satunya adalah, Pelaksanaan penelitian Pengembangan Media Game Math-Venture Terhadap Pemecahan Masalah Di Kelas IV Sekolah Dasar, dalam kenyataannya tidak dapat dilaksanakan dilapangan dikarenakan situasi dan kondisi saat ini masih terjadi pandemi Covid-19, dalam menyikapi hal ini, maka banyak sekolah yang melakukan kegiatan belajar mengajar dengan menggunakan sistem daring atau online, kemudian pengembangan game Math-Venture ini terfokus pada materi KPK,makna dari pengembangan ini adalah memudahkan siswa dalam melaksanakan pembelajaran menggunakan media game yang dapat diakses dimana dan kapan saja pengembangan ini sesuai dengan perkembangan keilmuan dimana sekarang ini menngunakan IPTEK sebagai bahan belajar sehingga memudahkan peserta didik untuk belajar KPK. Penelitian pengembangan game ini sejalan dengan penelitian yang dilakukan oleh (Denny dan Dadan 2021) yang mendapatkan hasil presentase keefektifan $92 \%$ masuk dalam kategori sangat tinggi

\section{SIMPULAN}

Produk yang dihasilkan peneliti adalah Game Math-Venture. Produk ini dapat digunakan untuk memberikan inovasi pembelajaran khususnya pada materi KPK. Hasil dari validasi produk game Math-Venture mendapat hasil validasi materi $81 \%$ termasuk dalam interval $81 \%-100 \%$ masuk dalam kategori sangat tinggi. Kemudian hasil validasi media memperoleh skor $91 \%$ termasuk dalam interval $81 \%-100 \%$ masuk dalam kategori sangat tinggi dan dengan rata rata hasil validasi $86 \%$ termasuk dalam interval $81 \%-100 \%$. Sehingga dalam pembuatan produk Game Math-Venture dapat dinyatakan produk pengembangan game Math-Venture ini layak untuk digunakan. Pengembangan Produk Game Math-Venture Terhadap Pemecahan Masalah menurut Polya di Kelas IV Sekolah Dasar mampu membantu siswa untuk menghadirkan suasana senang kepada siswa dan memotivasi belajar siswa meningkat. 
2356 Pengembangan Game Math-Venture terhadap Pemecahan Masalah Matematika Di Sekolah DasarHesti Agustianingrum, Yohana Setiawan

DOI: https://doi.org/10.31004/basicedu.v5i4.1221

\section{UCAPAN TERIMA KASIH}

Terimakasih kepada Tuhan Yang Maha Esa yang telah menyertai penelitian ini dari awal sampai selesai dengan baik. Mengucapkan terimakasih kepada kedua orang tua yang telah memberikan dukungan baik material maupun doa. Terimakasih kepada dosen pembimbing Yohana Setiawan, M.Pd yang telah memberikan bimbingan sehingga dapat terselesaikan dengan baik, Danang Setyadi, M.Pd sebagai validator materi, Adi Winanto, S.Pd., M.Pd. Sebagai validator media. Serta kepada semua pihak yang telah membantu.

\section{DAFTAR PUSTAKA}

Denny Rahmalia, Dadan Suryana. (2021). Pengembangan Media Papan Flanel untuk Meningkatkan Kecerdasan Logika Matematika pada Anak. Jurnal Basicedu.

Efendi, E \& Zhuang, H. (2005). E-learning Konsep dan Aplikasi. Andi offset.

Ely Wardhani, Novita., \& Rahmawati, I. (2020). Pengembangan Media Game Labyrinth Adventure Berbasis Android Sesuai Tahapan Pemecahan Masalah Polya Di Sekolah Dasar. Jurnal Penelitian Pendidikan Guru Sekolah Dasar, 8(1)

Faiq, A. (2012). Mathematics Adventure Game Berbasis Role Playing Game (RPG) Sebagai Media Pembelajaran Mata Pembelajaran Matematika Kelas V SDN Jetis 1. Jurnal Ilmiah Pendidikan.

H, Suhendri . (2011). Pengaruh Kecerdasan matematis-logis dan Kemandirian Belajar Terhadap Hasil Belajar Matematika. Formatif, 1, 29-39.

Kemendikbud. (2016). Permendikbud Nomor 22 Tahun 2016 tentang Standar Proses Pendidikan Dasar dan Menengah. Kementerian Pendidikan dan Kebudayaan RI.

Luthfya, \& Zaim, U. (2020). ) Pengembangan game edukasi “Beruang Pintar (Belajar Bangun Ruang Pintar) untuk memfasilitasi pemahaman konsep. Jurnal Pendidikan Matematika.

Mawardi. (2014). Model Desain Pembelajaran Kosep Dasar PKn Berbasis Belajar Mandiri Menggunakan Moodle. widya sari pres.

Mawardi. (2017). Designing the Implementation of Model and Instructional Media.

Meriam S. (2019). Analisi Kemampuan Pemecahan Masalah Matematika Siswa MTsN Dengan Menggunaan Metode Open Ended Di Banung Barat. Cendekia, 3, 178-18.

M, Askari Zakariah, Vivi Afriani, K. M. Z. (2020). Metodologi Penelitian Kualitatif, Kuantitatif, Action Research, Research and Development (R\&D). Yayasan Pondok Pesantren Al Mawaddah Warrahmah Kolaka.

Mulyasa, \& E. (2014). Pengembangan dan Implementasi kurikulum 2013. PT. Remaja Rosdakarya.

Nur Qurrota A'yun, Ika Rahmawati. (2018). Pengembangan Media Interaktif Si Pontar Berbasis Aplikasi Android Materi KPK Dan FPB Mata Pelajar Matematika Kelas IV SD. JPGSD.

Rabiah, Siti. (2015). Penggunaan Metode Research and Development dalam Penelitian Bahasa Indonesia di Perguruan Tinggi. Program Studi Bahasa dan Satra Indonesia. Fakultas Sastra.Universitas Muslim Indonesia.

Rita Ningsih, Arfatin Nurrahmah (2016). Pengaruh Kemandirian Belajar Dan Perhatian Orang Tua Terhadap Prestasi Belajar Matematika. Jurnal Formatif.

Ririn Windawati, Henny Dewi Koeswanti. (2021). Pengembangan Game Edukasi Berbasis Android untuk Meningkatkan Hasil Belajar Siswa di Sekolah Dasar. Jurnal Basicedu.

S, Akbar. (2013). Instrumen Perangkat Pembelajaran. PT. Remaja Rosdakarya.

Sugiyono. 2015. Metode Penelitian Kuantitatif. Kualitatif dan R\&D. Bandung Alfabeta. 
2357 Pengembangan Game Math-Venture terhadap Pemecahan Masalah Matematika Di Sekolah DasarHesti Agustianingrum, Yohana Setiawan

DOI: https://doi.org/10.31004/basicedu.v5i4.1221

Sunyoto Hadi Prayitno, Hanim Faizah (2019). Pengembangan Media Pembelajaran untuk Materi FPB dan KPK bagi Siswa Sekolah Dasar Kelas IV. UNION: Jurnal Pendidikan Matematika.

Vini ArianiErwin, Yarmis. (2019). Multimedia Interaktif Bermuatan Permainan Edukatif Di Kelas V Sekolah Dasar. Jurnal Basicedu.

Wijaya, E.Y, Sudjimat, D.A, N. A. (2016). Transformasi Pendidikan Abad 21 Sebagai Tuntutan Pengembangan Sumber Daya Manusia Di Era Global. Prosiding Seminar Nasional Pendidikan Matematika, 1, 263278. 